Henryk Wnorowski

Uniwersytet w Biatymstoku

\title{
Antropologiczne granice ekonomii
}

\section{ANTHROPOLOGICAL BOUNDARIES OF ECONOMICS}

The purpose of the article is to review the hypothesis that economics as a science, at least in its utilitarian aspects, encounters certain anthropological boundaries that limit its effectiveness. The author starts his argumentation with the outlining of historical context of contemporary economics, with particular regard to the concept of homo oeconomicus. Then he argues that cultural hegemony of the Western civilisation has made the concept of economic man believable. If so, the fundamental question is what are the sources of the problems of contemporary economies? Is it possible that economics as a scientific discipline cannot answer the questions of the causes of the crisis we are observing today? In his answering the question, the author points out two reasons:

- The split between economy and traditional Christian values. The author quotes a Chinese government economist Zhao Xiao - the author of an essay Market economies with Churches vs. Market Economies Without Churches, in which he formulates a thesis that the source of the Wester economic success results from the fear of the Last Judgement. 'Market economy is effective, as it prevents one from idleness, but can also encourage people to lie and hurt others . Therefore it requires moral support'. And this is guaranteed only by Christianity.

- Weakening the importance of responsibility in economic and political activity in today's economy.

Key words: economics, homo oeconomicus, economic freedom, crisis, fundamental values, responsibility. 


\section{Wstęp}

Człowiek jest istotą myślącą, społeczną, tworzącą i pracującą, bawiącą się, jest też istotą duchową przeżywającą transcendentnie i immanentnie obecność Boga. Pytanie o jego miejsce i zadania w różnych przestrzeniach, m.in., intelektualnej, gospodarczej i duchowej stworzonego świata od zawsze poruszało umysły myślicieli kreujących wiele koncepcji, niejednokrotnie skrajnych ${ }^{1}$.

Wśród mnogości koncepcji określających istotę człowieka i jego cele, z przyczyn naturalnych autor niniejszego artykułu zajmie się pojęciem homo oeconomicus, wszak świat ludzkich spraw to w dużej mierze świat gospodarki, pracy i różnych celów ekonomicznych, oraz przyczynami popularności tej koncepcji, a także jej słabymi stronami - obszarami do krytyki.

Encyklopedia katolicka opisuje zdefiniowaną osobę (homo oeconomicus) jako abstrakcyjny model zachowań człowieka, który jest wykorzystywany do badania jego postaw w dziedzinie życia gospodarczego, analizy i przewidywania masowych zachowań jego uczestników. Taki opis człowieka zakłada jego wolność i racjonalność oraz ukierunkowanie na maksymalizację subiektywnie określonych celów, także egoistyczną motywację i wyrachowanie w podejmowaniu gospodarczych decyzji. Społeczna nauka Kościoła formułuje zastrzeżenia wobec antropologiczno-aksjologicznych założeń liberalnej wizji homo oeconomicus, zamykającej człowieka wyłącznie na marginesie bezwzględnej maksymalizacji zysków ekonomicznych. Taka koncepcja wszak narusza integralną wizję osoby ludzkiej, zwłaszcza unikając poddawania moralnej ocenie motywów i sposobów zaspokajania potrzeb gospodarczych oraz mechanicznego funkcjonowania życia gospodarczego ${ }^{2}$. Należy się zgodzić, iż zastrzeżenia te nie są całkowicie bezpodstawne.

Zacznijmy od sformułowania problemu wstępnego uzasadniającego aktywność gospodarczą człowieka. Zakładamy, iż przyczyną ludzkiej aktywności jest potrzeba rozumiana jako uczucie braku czegoś. Mierząc się z tym problemem, ludzie podejmują działalność gospodarczą polegającą na przetwarzaniu zasobów przyrody. Potrzeby są nieograniczone, zasoby zaś wprost przeciwnie, stąd pojawia się uzasadnienie dla ekonomii jako nauki o gospodarowaniu na każdym poziomie agregacji. To ekonomia podpowiada nam jak postępować, aby w ramach posiadanych możliwości osiągnąć jak najwyższy poziom satysfakcji.

\footnotetext{
1 R. Samsel, Homo oeconomicus w katolickiej nauce społecznej, [w:] I. Celary, G.Polok(red.),Homo oeconomicus w pastoralno-społecznejprzestrzeni, Katowice 2013, s. 13.

2 J. Walkusz (red.), Encyklopedia katolicka, t. 6, Lublin 1993, kol. 1189-1190.
} 
Zależy to od człowieka uruchamiającego proces gospodarczy, to człowiek jest sprawcą wszelkiego doczesnego porządku, także porządku Nauka gospodarczego, sprawnie funkcjonujących systemów, jeśli nie buduje ich w sprzeczności do systemów naturalnych i do obowiązujących wartości. Ale ten sam człowiek jest/może być przyczyną nieporządku, wadliwych systemów i szkodliwych rozwiązań.

W świetle powyższych uwag, hipotezę główną niniejszego artykułu formułuję jako stwierdzenie, że ekonomia jako nauka, przynajmniej w swojej funkcji utylitarnej napotyka na pewne granice antropologiczne ograniczające jej skuteczność. Te granice mogą być rozumiane jako słabe strony ekonomii, bądź jako przyczyny jej ograniczonej skuteczności właśnie w swojej rekomendacyjnej funkcji. Generalnie tkwią one w człowieku, w wyznawanych przez niego wartościach i są wielostronnie warunkowane.

\section{Kontekst historyczny współczesnej ekonomii}

Historia współczesnej ekonomii rozpoczyna się w 1776 roku. Przez 6000 lat poprzedzających ową datę temat, który dominuje przez większość życia prawie każdego człowieka - zarabianie na życie - nie doczekał się żadnego kluczowego dzieła. Przez tysiąclecia, od czasów Rzymu poprzez wieki ciemne i renesans, ludzie w pocie czoła pracowali, by zapewnić sobie byt. Niekiedy ledwie uchodząc z życiem. Nieustannie groziła im śmierć, choroby, głód, wojna i niskie płace. Tylko niewielu szczęśliwców - głównie władców i arystokratów - żyło w dostatku i miało czas wypoczywać, ale nawet ich życie było skromne jak na nasze standardy. Życie zwykłych ludzi przez całe wieki prawie się nie zmieniało. Zarobki realne na głowę były takie same rok po roku, dekada po dekadzie. W owej epoce, gdy średnia długość życia w Anglii wynosiła 40 lat, Thomas Hobbes powiedział o życiu człowieka, że jest „samotne, nędzne, niemiłe, brutalne i krótkie”3.

I nadszedł rok 1776, gdy nadzieja i rosnące oczekiwania zapukały do serc zwykłych ludzi, za sprawą dwóch fundamentalnych wolności:

- wolności politycznej - amerykańskiej Deklaracji Niepodległości; 4 lipca 1776 Thomas Jefferson ogłaszając ,życie, wolność i swobodę ubiegania się o szczęście" niezbywalnymi prawami, położył tym samym prawne podwaliny nowego narodu,

- wolności przedsiębiorczości - w Londynie zostało opublikowane cztery miesiące wcześniej (9 marca 1776 r.) monumentalne dzieło: 
Badania nad natura i przyczynami bogactwa narodów - Adama Smitha. Autor zawarł tam uniwersalną receptę na bogactwo i finansową niezależność. Swoją wizję gospodarki nazwał systemem wolności naturalnej, dzisiejsi ekonomiści nazywają tę wizję modelem klasycznym, potocznie zaś bardzo często mówi się o gospodarce rynkowej.

Trzy fundamenty modelu klasycznego to:

- wolność: prawo do wytwarzania i wymiany towarów, pracy i kapitału zgodnie $\mathrm{z}$ interesem własnym,

- konkurencja: jednostki mają prawo do konkurowania w produkcji i wymianie dóbr,

- sprawiedliwość: działania jednostek muszą być uczciwe i sprawiedliwe, zgodne z normami społecznymi.

Adam Smith zauważył, że w działaniach rynkowych poszczególne jednostki, bazując na swojej racjonalności, dobierają optymalne środki w celu maksymalizowania własnych korzyści. Dlatego też człowiek taki zdobywa odpowiednią wiedzę, aby nakłonić drugiego do dogodnego dla siebie kontraktu. Odwołuje się wtedy do egoizmu drugiej osoby, albowiem przyświeca mu podobny cel.

Daj mi to, czego ja chcę, a otrzymasz to, czego ty chcesz: oto znaczenie każdej takiej propozycji, i to jest właśnie sposób, w jaki otrzymujemy nawzajem od siebie największą część usług, których potrzebujemy. Nie od przychylności rzeźnika czy piekarza oczekujemy naszego obiadu, lecz od ich dbałości o własny interes. Zwracamy się nie do humanitarności, lecz do egoizmu i nie mówimy im o naszych własnych potrzebach, lecz o ich korzyściach ${ }^{4}$.

\section{Przyczyny popularności koncepcji homo oeconomicus}

Koncepcję tak myślącego człowieka rozwinął John Stuart Mill, który jeszcze bardziej sprowadził go do teoretycznego modelu. Dla Milla homo oeconomicus był człowiekiem, który to, co mu niezbędne, przydatne i luksusowe starał się pozyskać przy minimum wysiłku i wyrzeczeń. Jego koncepcja odnosiła się do natury człowieka przedstawionej wcześniej przez Adama Smitha, dla którego jednostka jest wolna i egoistyczna, ale przez koncentrację na własnym interesie zmuszona do współpracy i wymiany, przyczynia się do dobra ogólnego 5 .

\footnotetext{
4 A. Smith, Badania nad natura i przyczynami bogactwa narodów, Warszawa 1954, s. 20.

$5 \quad$ H. Olszar, Krytyka technokratycznej koncepcji homo oeconomicus w nauczaniu Jana Pawta II, [w:] I. Celary, G. Polok (red.), Homo oeconomicus..., dz. cyt., Katowice 2013, s. 29.
} 
W potocznym znaczeniu homo oeconomicus łączy racjonalizm z egoizmem. Jest on człowiekiem, który postępuje racjonalnie. Cechuje go Nauka działanie oparte na kalkulowaniu nakładów i efektów oraz dążenie do uzyskania optymalnych rezultatów. Jego działania opierają się na zasadzie minimaksu. Jeżeli jest producentem, dąży do maksymalizacji zysku, jeżeli jest konsumentem, dąży do maksymalizacji użyteczności.

Człowiek uwikłany w działania ekonomiczne pojmowany jest od strony antropologicznej jako istota skłonna do wymiany, handlu i zamieniania jednej rzeczy na drugą. Posiada swą wolność, którą w bezapelacyjny sposób wykorzystuje do osiągnięcia jak największych korzyści własnych. Zarazem potrzebuje społecznego odniesienia, potrzebuje innych ludzi do realizacji swych zamierzeń, w wyniku których następuje akt wzajemnej wymiany i współpracy ${ }^{6}$. Ten wygodny, bo upraszczający sprawę pogląd o powszechnym nastawieniu na zysk i niekończącą się konsumpcję, jako naturalnej skłonności człowieka, pozwalający na formułowanie uniwersalnych praw ekonomicznych jest jednak nie do końca prawdziwy. Przynajmniej nie we wszystkich okolicznościach i nie we wszystkich kulturach.

Odmienne systemy wartości, znajdujące wyraz w zróżnicowanych potrzebach, aspiracjach i definicjach satysfakcji czy szczęścia prezentuje antropologia ekonomiczna. Bronisław Malinowski dowodzi, że kategorie pojęciowe i schematy analityczne właściwe dla nauki ekonomii, czyli gospodarki cywilizacji zachodniej, nie pasują do opisu i wyjaśniania specyfiki gospodarki mieszkańców Wysp Trobriandzkich. Marshall David Sahlins charakteryzuje gospodarkę pierwotną plemion łowców-zbieraczy jako gospodarkę względnego dobrobytu, który jest następstwem relatywnie ograniczonych potrzeb. Wolni od imperatywu posiadania dóbr i ich akumulacji, nie wiążą tak rozumianego stanu majątkowego ze statusem społecznym. Nie obarczając się ich bagażem, mogą skutecznie realizować swój styl życia niejednokrotnie wymagający ciągłych wędrówek w poszukiwaniu nowych źródeł pożywienia. Jeśli w komentarzach do tej ekonomii mówi się niejednokrotnie o „ubóstwie”, „,beztrosce”, „niezaradności”, „braku ambicji”, ,stagnacji”, „zacofaniu”, „prymitywizmie”, o tym wreszcie, że dopiero przełom neolityczny, z jego uprawą roli i hodowlą zwierząt, poprawił poziom życia ludzi, popełniany jest typowy błąd rzutowania „fetyszyzowanych kategorii współczesnej gospodarki kapitalistycznej" na obcy jej formule, inny, co nie znaczy gorszy, sposób gospodarowania i styl życia?

M. Kopias, Cnota egoizmu u homo oeconomicus, [w:] I. Celary, G. Polok (red.), Homo oeconomicus..., dz. cyt., Katowice 2013, s.. 165. 
$\mathrm{Na}$ tle postępującego procesu unifikującej kulturowo globalizaNauka cji, generującego prawodawczy punkt odniesienia opisu i oceny, te obrazy alternatywnych sposobów gospodarowania stają się jednak nieuchronnie coraz bardziej odległe i egzotyczne, znamionujące styl życia społeczności wyraźnie odstających od prawomocnej normy tym procesem wyznaczanej. Liczne koncepcje ekonomiczne są tylko dlatego uznawane za wybitne, ponieważ zostały stworzone dla opisu dominującej gospodarki. Wydaje się, że można sformułować tezę, iż to gospodarka kapitalistyczna uwiarygodniła koncepcję człowieka ekonomicznego. Hegemonia kulturowa cywilizacji zachodniej, czyli systemu społeczeństwa rynkowego wydaje jednoznaczny werdykt, które doktryny są właściwe ${ }^{8}$.

\section{Ekonomia a wyjaśnianie przyczyn obecnych zjawisk}

Skoro tak, to nasuwa się kolejne fundamentalne pytanie, skąd biorą się kłopoty współczesnych gospodarek? Czyżby ekonomia jako dyscyplina naukowa nie radziła sobie $\mathrm{z}$ odpowiadaniem na pytania o przyczyny obserwowanych zjawisk kryzysowych? Jak zauważył prof. Jerzy Wilkin, jedno z najważniejszych pytań stawianych w czasie niedawnego IX Kongresu Ekonomistów Polskich brzmiało: czy obecny kryzys gospodarczy, a zwłaszcza finansowy, oznacza także kryzys ekonomii jako nauki? W referatach często podkreślano, że ostatnie dekady zaowocowały rozwojem wielu wyrafinowanych modeli i teorii ekonomicznych. Przeważał jednak pogląd, że ekonomia utraciła duszę, źródło wrażliwości i osądu moralnego. Zapewne utrata tej duszy nie pozwala wielu ekonomistom zrozumieć swoich grzechów i błędów. Po wybuchu kryzysu 2008 roku na głowy ekonomistów posypały się gromy. Uzasadnione. Przez co najmniej trzy dekady bardzo wpływowi ekonomiści pod hasłami wolności, dobrobytu, a nawet demokracji wspierali bowiem rozwiązania systemowo-instytucjonalne, które do tego kryzysu doprowadziły. Dziś wypada spojrzeć prawdzie w oczy i uderzyć się w piersi. W ekonomii, w systemie instytucjonalnym

8 „Dominującą ekonomią była i jest ekonomia dominującej gospodarki. Ekonomia brytyjska tak długo królowała, jak długo czołową pozycję zajmowała Wielka Brytania. Potem jej pozycję zajęły Stany Zjednoczone i ekonomia amerykańska. Gdyby nauka o gospodarce w znaczącej mierze rozstrzygała o stanie gospodarki, wówczas pozycja ekonomii brytyjskiej czy amerykańskiej byłaby w pełni uzasadniona. Nie ma dowodów, że tak jest, a liczne koncepcje ekonomiczne są tylko dlatego uznawane za wybitne, ponieważ zostały stworzone dla opisu dominującej gospodarki". R. Bartkowiak, Historia myśli ekonomicznej, Warszawa 2008, s. 28. 
gospodarki i w polityce ekonomicznej dużo musi się zmienić, byśmy wyszli z tego kryzysu i uniknęli jeszcze ostrzejszych w przyszłości ${ }^{9}$.

Nauka

Dla autora niniejszego opracowania, to co się stało jest w jakimś sensie konsekwencją antropologicznych ograniczeń ekonomii jako nauki. Skupia się on na wskazaniu dwóch okoliczności, niekonsekwencji, czy inaczej, słabych stron ekonomii.

Rozpoczynamy od spojrzenia z perspektywy innych kultur na przyczyny sukcesu świata zachodniego. Jakie są źródła faktu, że to właśnie Europejczycy zawojowali świat, że to nasza wersja gospodarki, polityki, filozofii podbiła świat? Dla nieuprzedzonych badaczy sprawa jest dość oczywista: przyczyną tego sukcesu jest chrześcijaństwo. To ono sprawiło, że Europa i Stany Zjednoczone otworzyły się na wolny rynek, zbudowały demokratyczne struktury, zbudowały technikę i naukę i za pośrednictwem tych elementów zawojowały świat ${ }^{10}$.

Ekonomista rządu chińskiego Zhao Xiao - autor eseju Gospodarki rynkowe z Kościołami a gospodarki rynkowe bez Kościołów - formułuje tezę, iż źródłem zachodniego sukcesu gospodarczego jest lęk przed Sądem Ostatecznym. „Gospodarka rynkowa jest skuteczna, ponieważ zniechęca do próżniactwa, lecz może także zachęcać do kłamstwa i krzywdzenia innych. Dlatego wymaga moralnej podpory". A tę daje wyłącznie chrześcijaństwo, które przypominając, że przyjdzie nam zdać sprawę z naszego życia przed Wszechmocnym, sprawia, że gospodarka rynkowa ma duszę, a jej uczestnicy nie zabijają się wzajemnie, ale budują wspólny rynek.

Zhao wcale nie jest w takiej diagnozie osamotniony, inni chińscy intelektualiści, często pozostający na partyjnym garnuszku, także coraz otwarciej przyznają, że chrześcijaństwo jest najszybszą i najpewniejszą drogą do modernizacji Chin. Wolny rynek, demokracja i nowoczesność są, ich zdaniem, osadzone w chrześcijaństwie tak ściśle, że nie sposób ich od siebie oddzielić. U podstaw sukcesu Zachodu leży zatem, nawet zdaniem chińskich komunistów, antropologia chrześcijańska, a szerzej chrześcijańska wizja świata, z wiecznym piekłem, które uświadamia odpowiedzialność za własne czyny, z osobową koncepcją Boga, wizją grzechu pierworodnego i Zbawienia. Te absolutne fundamenty wiary chrześcijańskiej stają się podstawą sukcesu - nie tylko w wymiarze wiecznym, ale także jak najbardziej doczesnym.

Thomas Eliot - laureat Nagrody Nobla w Idei społeczeństwa chrześcijańskiego przekonywał, że kultura demokratyczno-liberalna bez

10 B. Biela, Świat gospodarki a wyzwanie nowej ewangelizacji, [w:] I. Celary, G. Polok (red.), Homo oeconomicus..., dz. cyt., Katowice 2013, s. 52. 
wartości i tradycyjnej moralności chrześcijańskiej przekształca się w swoją nędzną parodię.

Niszcząc wśród ludzi tradycyjne zwyczaje, rozkładając naturalną świadomość zbiorową na świadomość jednostkową, sankcjonując opinie najgłupszych, zastępując edukację instruktażem, popierając spryt raczej niż mądrość, karierowiczów, a nie ludzi wykwalifikowanych (...) liberalizm może przygotować drogę do czegoś, co jest jego własnym zaprzeczeniem $^{11}$.

Wreszcie Benedykt XVI - w encyklice Caritas in veritate mówi, iż jedynie spójna wizja rzeczywistości społeczno-ekonomicznej otwartej na Boga i otwartej na przyjęcie Objawienia zawartego w Piśmie Świętym daje szansę, by życie społeczne nie było polem walki o wpływy, pieniądze i idee, a stało się przestrzenią wzrostu miłości. „Bez Boga człowiek nie wie, dokąd zmierza i nie potrafi nawet zrozumieć tego, kim jest”. „Kiedy państwo promuje, naucza lub wprost narzuca pewne formy ateizmu praktycznego, pozbawia swoich obywateli siły moralnej i duchowej niezbędnej do zaangażowania się w integralny rozwój ludzki".

Drugą okolicznością przesądzającą o słabości ekonomii w objaśnianiu współczesnych zjawisk jest osłabienie znaczenia odpowiedzialności w działalności gospodarczej i politycznej. Termin odpowiedzialność jest w języku potocznym wyraźnie zdefiniowany i określa konieczność odpowiadania za swoje postępowanie oraz jego skutki. Odpowiedzialną osobę charakteryzuje świadomość nieuchronności obowiązku uwzględnienia konsekwencji swoich działań. Zagadnienie odpowiedzialności w gospodarce ma starożytne korzenie, niestety dzisiaj mamy w tym obszarze do czynienia ze znaczącymi modyfikacjami.

Ekonomiści chętniej dzisiaj mówią o wolnym rynku niż o wolnym człowieku. Owszem, wolność gospodarcza jest bardzo ważnym składnikiem wolności, lecz tylko składnikiem. W Polsce i w innych krajach byłego imperium sowieckiego wiemy dobrze, jak bardzo brak wolności gospodarczej ograniczał osobistą i polityczną wolność. Jednak upadek komunizmu, konsensus waszyngtoński, reaganomics, thatcheryzm i triumf ekonomii neoliberalnej odpowiadają za pojawienie się trzech grzechów głównych w podejściu do ekonomii. Pierwszy to umocnienie przekonania, że cechy „człowieka ekonomicznego” dobrze służą postępowi ludzkości. Drugim było uwolnienie dżina powszechnej finansyzacji i tolerancji dla gigantycznej nierównowagi w finansach publicznych i prywatnych. Natomiast trzeci grzech polegał na wpojeniu

11 T. S. Eliot, Chrześcijaństwo, kultura polityka, tłum. P. Kimla Warszawa 2007, s. 33 . 
wielu ludziom i rządom przekonania, że nadmierna konsumpcja sprzyja rozwojowi gospodarczemu ${ }^{12}$.

Wdaje się, że te trzy grzechy wskazane przez prof. J. Wilkina są w dużej mierze konsekwencją właśnie „rozmycia” odpowiedzialności. Niestety, w dzisiejszych czasach i dzisiejszych systemach mamy do czynienia z olbrzymią asymetrią. Racjonalna analiza zysków i kosztów została zastąpiona rachunkiem szczęśliwości w mocno specyficznym układzie, gdzie:

- przyjemności są moje,

- ewentualne przykrości dotkną kogo innego ${ }^{13}$.

Nassim Nicholas Taleb formułuję tezę, iż największym producentem kruchości w społeczeństwie i największym generatorem kryzysów jest system, w którym nie ryzykuje się własną skórą. Niektórzy zyskują antykruchość kosztem innych, gdyż czerpią korzyści (lub zyski) narażając innych na ryzyko spowodowanych przez nich strat lub szkód. Jesteśmy świadkami narodzin nowej klasy antybohaterów, czyli biurokratów, bankierów, członków MZSz (Międzynarodowego Związku Szpanerów) uczestniczących w Forum w Davos (także często profesorów), polityków zadłużających ponad miarę przyszłe pokolenia. „Jeszcze nigdy w historii tak wielu nie ryzykantów, czyli ludzi nie narażonych osobiście na niebezpieczeństwo, nie sprawowało tak wielkiej kontroli. Tymczasem podstawowa zasada etyczna brzmi: nie będziesz korzystał z antykruchości kosztem kruchości innych"14.

\section{Konkluzja}

Czy w związku z tym jest jakieś rozwiązanie upoważniające nas, chociaż do minimalnego optymizmu? Jak najbardziej, odpowiedź jest pozytywna ${ }^{15}$. Wydaje się, że takim rozwiązaniem są działania w kilku

$12 \quad$ J. Wilkin, Dlaczego ekonomia..., dz. cyt., s. 16.

13 A. Adamus-Matuszyńska, Homo oeconomicus $w$ dobie idei społecznej odpowiedzialności, [w:] I. Celary, G. Polok (red.), Homo oeconomicus..., dz. cyt., Katowice 2013, s. 182.

14 N. N. Taleb, Antykruchość. O rzeczach, którym stużą wstrząsy, tłum. O. Siara, Warszawa 2013, s. 491-532.

15 Ekonomia to piękna nauka, pod warunkiem że jest nauką, a bardzo często nie jest. Wielu ludzi określających siebie i będących przez innych określanych ekonomistami z nauką ma niewiele wspólnego. Zajmują się bowiem lobbingiem na rzecz grup interesu, których interesy próbują narzucać, czasami niestety skutecznie, jako ogólnospołeczne, a niekiedy wręcz i cywilizacyjne, bądź też wikłają się w zażarte spory ideologiczne i stają się doktrynerami, dogmatykami, a nie teoretykami. Ale tak długo, jak to jest nauka, która dochodzi istoty rzeczy, 
obszarach zmierzające do redukcji otaczającej nas zewsząd hipokryzji, na którą składają się:

- większy szacunek względem samego siebie,

- wychowywanie młodych pokoleń w poszanowaniu dla fundamentalnych wartości,

- głoszenie prawdy,

- doskonalenie instytucji,

- praca uruchamiająca procesy produkcyjne, w trakcie których wytwarzana jest wartość dodatkowa pozytywnie wpływająca na poziom dobrobytu ogólnonarodowego.

Społeczeństwo ekonomiczne polega na zbudowaniu odpowiednich proporcji pomiędzy systemem wymiany, przymusu oraz integracji, które odwołują się do społecznie uznawanych wartości. Prawidłowo funkcjonujące społeczeństwo musi zbudować system równowagi pomiędzy trzema wymienionymi elementami. Dominacja któregoś z tych elementów prowadzi do destabilizacji, czyli zachwiania systemu wartości. System wymiany, czyli biznes, potrzebuje czynnika stabilizacyjnego, jakim jest odpowiedni system przymusu w postaci instytucji organizujących tę sferę działania oraz systemu integracji, który tworzy określone wartości, wokół których skupia się biznes i ludzie. Ani jednostka, ani też organizacja nie mogą być skuteczne bez podpory, jaką jest konkretny system uznawanych wartości ${ }^{16}$.

Jak zauważa Kenneth Boulding, napotykamy problem zapewnienia odpowiednich proporcji. Jeśli społeczeństwo biznesu ma przetrwać, musi rozwijać system i instytucje integrujące, przy czym instytucje dlań specyficzne (rynek, korporacje, banki itp.), mające w zasadzie charakter instrumentalny, nie są zdolne do rozwijania silnych systemów integracji we własnym zakresie. Przeto instytucje rynkowe winny być uzupełnione zespołem instytucji integrujących, takich jak rodzina, Kościół, szkoła i naród, które rozwijają indywidualne systemy wartości, zasadzające się na miłości, samopoświęceniu, identyfikacji z celami pozaosobistymi oraz altruizmie. Problemem społeczeństwa jest znalezienie właściwych proporcji. Nadmierna dominacja systemu przymusu,

a mianowicie odpowiada na pytanie, co od czego zależy w społecznym procesie gospodarowania, który staje się coraz bardziej skomplikowany w wyniku nieodwracalnej globalizacji, to jest piękną nauką, którą plasuję pomiędzy dwoma królowymi, z jednej strony miękką, abstrakcyjną filozofią, a z drugiej twardą, precyzyjną matematyką. Dobry ekonomista musi umieć liczyć, bojednak chodzi o to, aby w społecznym procesie gospodarowania efekty przewyższały nakłady. I dobry ekonomista musi czuć, co zbliża go do drugiej królowej - filozofii. G. W. Kołodko, Kto jest dobrym ekonomista, „Biuletyn PTE”, nr 1/2014, s. 12. 
systemu rynkowego czy systemu integracji powoduje zazwyczaj rozkład życia moralnego, a nawet dezintegrację społeczeństwa ${ }^{17}$.

Czy widzę jakieś postępy w tym względzie?

Tak, jednak ciągle jeszcze nie w pełni satysfakcjonujące!

Słowa kluczowe: ekonomia, homo oeconomicus, wolność gospodarcza, kryzys, wartości fundamentalne, odpowiedzialność.

17 K. E. Boulding, Etyka ibiznes, [w:] J. Grosfeld (red.), Ponad ekonomia, Warszawa 1985 , s. 68-69. 